\title{
The institutionalisation of populist political discourse and conservative uncivil society in the European Union
}

From the margins to the mainstream?

\section{Carlo Ruzza}

School of International Studies, University of Trento, Italy

\begin{abstract}
This article analyses the ideational features of conservative civil society groups at EU level and compares them to progressive groups. Through a frame analysis of the textual materials of these two types of organisations, I examine their reactions to the success of populist formations in several European member states and at EU level. I argue that the long-established EU ethos of fostering progressive civil society is undergoing a redefinition, which impacts their strategies. I posit that in a changing political climate, EU institutions are less interested in some of the contributions progressive civil society offers, such as its contributions to public deliberation, governance, and the legitimacy of the EU. Progressive civil society reacts to the threat of a loss of standing and attempts to retain its historical centrality, legitimacy, and access. In contrast, conservative civil society groups seek to establish themselves in a political environment previously off-limits to them.
\end{abstract}

Keywords: populist political discourse, civil society, public deliberation, frame analysis, EU

\section{Introduction}

This article focuses on the impact of populist discourse at EU level and particularly its impact on civil society organisations (CSOs). It identifies two broad families of CSOs: progressive and conservative civil society groups. I argue that, following the successes of radical-right populist formations in recent years, the long-established EU ethos of fostering and enabling socially progressive and inclusionary civil society groups is undergoing a redefinition. Concepts such as community, belonging, and solidarity - which have traditionally been associated with universalist, cosmopolitan, tolerant, and inclusive conceptions - are redefined in narrower terms by an emerging organisational environment of conservative civil society groups, which are gradually establishing themselves in the EU environment. At the same time, progressive civil society groups react to the impact of populism, but in part seek to retain their associational representative claim

Ruzza, C. (2021). The institutionalisation of populist political discourse and conservative uncivil society in the European Union: From the margins to the mainstream? Nordicom Review, 42(S1), 119-133. https://doi.org/10.2478/nor-2021-0010 
towards EU institutions by downplaying their relevance in the EU domain (Saward, 2010). This brings about a change in the role of civil society, which becomes segmented in terms of strategies and values.

Methodologically, the article is based on a frame analysis of a set of EU-level programmatic texts by civil society groups, and it illuminates the contrasts between progressive and conservative associations on key concepts such as EU-regulated antidiscrimination policies, views on EU fundamental rights, and the overarching functions of civil society, its composition, and mechanisms of legitimation. In this context, I discuss the concept of uncivil society and relate it to the relevant literature and argue that a process of institutionalisation of populist values is partially underway, resulting in a redefinition of the role and functions of civil society. However, I contend that this process is far from complete. The best way to frame the contrast between rival images of civil society, I posit, is through a movement-counter-movement dynamic in which populist views compete with and contrast inclusionary antidiscrimination non-populist views. It is competition between these two camps that characterises the current state of the field of civil society.

\section{The changing role of civil society in the $\mathrm{EU}$ : From a legitimating tool to a problematic concept}

Since its inception, the EU has been a strong supporter of the involvement of public and private interest groups in its decision-making processes. There are several reasons for this stance. Notably, a favourable disposition towards interest groups is motivated by the fact that a scarcely authoritative and complex decision-making process must rely on an aggregation of consensus among stakeholders before decisions can be taken and on detailed information about the technical and social aspects of decisions. Information provision and consensus aggregation are facilitated by the involvement of public and private interest groups.

A longstanding ethos of civil society involvement has produced a large, and often Commission-financed, group of CSOs with headquarters in Brussels and branches in the member states. It has also legitimated a political discourse strongly supportive of civil society and its involvement in EU policy processes; civil society has reciprocated this support by often expressing pro-European views. While critical of some aspects of the EU system of governance, many CSOs have expressed their support for the "European Project". However, as a value-based project, the ethos of European integration resonated with a particular type of civil society - the progressive, socially inclusionary type, which values broad participation, antidiscrimination EU policies, and the promotion of human rights (Saurugger, 2016).

This political context lasted for several decades, and the glorification of civil society peaked at times when the Union attempted significant advances in integration, as in the run-up to the then failed Constitutional Treaty. In several EU documents of that period, and also in several academic publications, civil society is closely associated with values of social inclusion and support for the democratic process. However, in the following years, this unquestioned reliance on civil society diminished. Civil society remained an important focus of several EU institutions, but less so than in previous years. A crisis of civil society involvement has been noted by workers and volunteers in the sector and 
during in-depth interviews, they often speak of a "shrinking space" for civil society (Grote, 2019). There are diverse reasons for this change, and they are only partly related to the populist challenge. They include the fact that the EU has long abandoned the strong integrationist approaches of a few decades ago and no longer needs the type of legitimation mentioned above and the fact that the civil society of recent years is more professionalised and inspired by new public management standards of accountability and reliability, which are not always provided by CSOs. However, an important factor is a political change in several key member states which have witnessed the growing impact of radical-right populist forces that are often sceptical of the involvement of CSOs, and particularly of progressive, EU-level ones.

In the past decade, populist parties have made substantial advances in several EU countries, differing in terms of geographical location, but also in types of political cultures, religions, and levels of affluence. This impact is reflected in EU institutions, which, as I will argue, also has an impact on CSOs. The "populist turn" is important at EU Council level because some populist parties are in incumbent positions and can strongly affect EU policy-making. It is crucial in the EU Parliament, because even if there is a working cordon sanitaire successfully marginalising them, they have a discursive impact on other parties (Wodak, 2017). Thus, one encounters in recent years a political environment in which Eurosceptic radical right populists have gained traction, and this negatively affects CSOs.

There are several reasons why relations between CSOs and populists are difficult. A general reason is the principled opposition of populist forces to intermediate social bodies, such as CSOs. The populists' dislike of intermediary institutions is wide ranging and characterises left-wing and right-wing populisms. Since anti-elitism is a defining dimension of populism, civil society groups are seen as elite formations which undermine populists' asserted cohesion of "the people" - a defining category of all populist ideologies, which is regularly present within the large conceptual contents characterising these ideologies (de la Torre \& Mazzoleni, 2019). A second element connected to the ideological assertion of the cohesive nature of "the people" is the refusal to attribute a superior status to "experts" (Collins et al., 2020). Civil society advocacy efforts are often based on claims to expertise not readily accepted by populist groups. A related aspect is populists' preference for conceptual and linguistic simplification. As the politics of expertise is generally based on complex technical or social-scientific knowledge, CSO experts tend to be distrusted by populists. Thirdly, and with specific reference to the EU level, many CSOs have undergone a process of institutionalisation in the EU political environments, whereby they often express the values of their funding institutions, which tend to be pro-EU values in the EU context. Thus, populists often oppose EU-level civil society not only in general, but for expressing the views of the specific political context in which it operates.

Nonetheless, while there are several reasons why populist formations are at loggerheads with organised civil society, there are also reasons why right-wing populist actors do not eschew all associations. Some like-minded civil society groups can be useful to radical-right populist parties in a number of ways. They can, for instance, help in service delivery, or as a means to campaign in favour of their signature policies and their conservative agenda on matters such as combatting abortion rights, promoting "family values", and other conservative issues like uncompromising positions on drugs 
and end-of-life rights. Thus, the attitude of radical-right populists towards civil society is ambivalent.

The political values of populist-supported governments of some member states find an echo in the conservative civil society groups that are present at the EU level, and they are therefore endorsed, while other CSOs are disbelieved. Before examining the political discourse of the opposed EU families of CSOs, it is useful to contextualise them in their political environment.

At the EU level, CSOs have been almost exclusively of the progressive, inclusionary type. With their role mainly one of advocacy, even service-delivery organisations concentrate on their advocacy efforts. EU institutions encouraged and financed CSOs at the EU level for legitimacy reasons, and they are generally umbrella groups with a base in member states. Conversely, non-progressive CSOs are few. Some of them are fully compatible with the established EU values, that is, with "the values of respect for human dignity, freedom, democracy, equality, the rule of law and respect for human rights, including the rights of persons belonging to minorities", which are sanctioned by Article 2 of the Treaty on European Union (European Union, 2012: 17). However, some of them are not, and are thus closer to the rejection of these values, professed by radical-right populist political formations. This sharply differentiates two groups of CSOs. I conceptualise conservative uncivil society as civil society groups whose ideology violates the values of anti-discrimination and human rights that are constitutionalised in liberal democracies. Not all conservative CSOs do so, but several do.

I argue that, at the EU level, these groups echo some of the same ideological preferences manifested by populist parties in the European Parliament and by populist governments represented in the European Council, but not all. Both types of organisations engage in boundary-making, defining the other family of CSOs as fundamentally different and ideologically mistaken.

\section{Methodology}

To study boundary-making in the EU civil society field, and CSOs' political discourses, a database of civil society texts was constructed and content-analysed using a qualitative technique. Available sources were EU civil society websites. This database was constructed to sample civil society opinions on issues related to populism and thus maximise the contrast between progressive civil society groups and civil society groups supporting the values and policies of radical-right populist groups. These were those identified in the literature on right-wing populist formations that emphasise their enemythinking, nationalism, Euroscepticism, and reservations on the checks and balances of liberal democracy.

The selection process consisted of locating civil society texts available online and classifying them while progressing sequentially from the beginning of the past legislature until mid-2020. Any document that contained references to at least two keywords related to themes identified as populist-relevant was selected from civil society websites. There were nine keywords utilised to select texts: populism, discrimination, hate speech, xenophobia, Euroscepticism, migration, Brexit, European democracy, and European values. Based on the relevant literature defining populism, these were areas in which the different worldview of populists and non-populists was maximised. 
Based on an interview-based classification of progressive and conservative CSOs, the database was distinguished by CSOs belonging to the progressive and conservative families. The progressive family of CSOs, which is described in more details later, included 18 antidiscrimination networks such as ENAR (the European Network against Racism), ILGA-Europe (the EU branch of the International Lesbian and Gay Association), and human rights associations. The CSOs documents identified and frame-analysed for the period 2012-2020 were 424. Conservative groups included four associations, such as Agenda-Europe and ECPM (the European Christian Political Movement), for a sample of 37 documents. The different size of the database reflects the fact that EU civil society is still largely dominated by progressive CSOs.

On the basis of this database, it was possible to examine which of these topoi are central to the two families of CSOs and which are peripheral in their discourse: how they conceptualise populism, how they relate to it, and whether contrasting views are expressed by different types of organisations. In order to do this, a structured reading of the texts was performed using the methodology of frame analysis (Matthes, 2009). The objective was to identify a socially recurrent set of themes to then be able to quantify their prominence in the database. Then their frequency and proximities were counted using content-analysis software (Atlas Ti 8.4).

Before illustrating the findings of the frame analysis of the conservative uncivil society family of CSOs, it is useful to provide some context on the two families of associations, starting with the larger and established body of progressive CSOs.

\section{Findings: Progressive civil society and its opposition to conservative uncivil society}

Overall, the frame analysis shows a clear contrast between conservative and progressive CSOs. The conservative organisations identified disrespected the ethos of antidiscrimination and human rights that is legally entrenched in the EU system. They can then be classified as expressions of conservative uncivil society (CUCS), with reference to the large body of literature on uncivil society (see, e.g., Krzyzanowski \& Ledin, 2017; Ruzza, 2010).

A first overarching finding is how these different types of CSOs conceptualise themselves and their rivals. While progressive civil society is mainly concerned with itself, it does not seem to focus on CUCS. There are few direct references to CUCS, showing that for EU-level CSOs, civil society is still mainly of the progressive inclusionary kind. When this takes place, instead of naming specific organisations, EU-level CSOs mention an unspecified civil domain. For instance, FEMYSO, an EU-level organisation representing Muslim Youth in Europe notes,

Physical and verbal attacks, threats against human rights defenders, women, migrants and minorities became common in civil society space. For these reasons, there is an urgent need of a tool to strengthen the protection and promotion of the civil society space in Europe. (FEMYSO, 2018)

There are several reasons why CUCS is relatively absent from the considerations of EU-level civil society actors. Primarily, acknowledging the presence of conservative CSOs would undermine the claim to representation implicitly and very often explicitly advanced by progressive civil society. 
Thus, the frame analysis produced by progressive CSOs shows that the wording "civil society" occurs 314 times. Therefore, these CSOs claim to address themselves and EU institutions on behalf of all civil society. This amounts to a key representative claim of non-elected advocacy groups (Saward, 2010). To be able to claim a legitimate representational role, progressive CSOs need to ignore civil society groups with incompatible values. Conservative CSOs' still limited relevance implies that their presence can be ignored for the time being.

As shown by personal interviews, they perceive CUCS as an extension of right-wing groups. They consider these organisations to be manufactured, or at least heavily supported, by populist governments, thus not true instances of CSOs. They therefore focus on right-wing governments and politics. The frame analysis shows that this is a recurrent area of concern. Progressive EU-level civil society groups refer negatively to far-right politics 190 times, to fascism as a threat 36 times, to populism 67 times, and to hate speech and crimes 236 times. From these findings, it emerges that the main concern of CSOs is hate speech, which is shared by all types of antidiscrimination groups and human rights groups, but particularly by antiracist and LGBT-rights groups. References to conservative civil society sometimes occurred implicitly in the excerpts and interviews, but they are infrequent, while they are often central in the texts of CUCS.

\section{Conservative uncivil society}

As mentioned, at the EU level, the direct presence of conservative populist groups is still rather limited, and their documents are not easily identified. Only 37 documents were clearly identified and analysed. However, this sample provides a clear view of their values and differences with progressive CSOs. Before discussing the framing results, it is useful to contextualise CUCS.

At the EU level, there are international conservative CSOs that have established a presence in some member states and can then liaise with national organisations and apply for EU funds. They can represent their views in the EU Parliament through likeminded members of parliament, and they can address the public sphere in member states but appeal to a broader EU-level constituency.

The ecology of EU-level conservative associations is formed by a complex and internally differentiated set of organisations. As a member of the European Economic Committee working with civil society notes in a 2019 interview, they are generally cautious in occupying a niche in the EU civil society domain, because they are aware that their discourse clashes with the dominant ethos of progressive civil society and with the pro-European ethos of EU institutions. Thus, this family of CSOs is occasionally invited to institutional meetings, but it does not often conspicuously advertise its difference from the isomorphic field of progressive civil society within which the values of human rights and antidiscrimination are taken for granted. This difference is nonetheless clearly evident in their position papers.

Associations represented in Brussels express a diluted form of the exclusionary values that characterise more militant groups. This is necessary, for otherwise, they would clash with the previously mentioned institutionalised political values of the EU. Other aspects that clash with an antipluralist stance of populist formations are specified in Article 3 of the Treaty on European Union and include a commitment to combating social exclusion 
and discrimination. Violations of these values can potentially lead to the sanctions envisaged by Article 7, which may include suspension of the voting rights of a member state (European Union, 2012). For these reasons, the most extreme uncivil society formations are excluded from the EU governance system and self-exclude because any EU presence would be irrelevant. This is the reason more extreme CSOs have not been found by my examination of websites and is in itself a finding to be noted.

However, a typology of uncivil society would also include antipluralist views that fall within the category of uncivil society rejecting EU values of civility, but not openly or aggressively articulating those preferences. They would be characterised by an exclusionary political frame naturalised and presented as a lifestyle choice. This type is more likely to appear compatible with the wide diversity of views represented in the EU arena. These CSOs are then organisations that are objectively at odds with the EU sanctioned values of tolerance and antidiscrimination, as well as with the values of Western democracies. These formations are best characterised as "conservative uncivil society" because their exclusionary values are generally justified in terms of a restrictive conceptualisation of the population deserving to be included in society, such as traditional families, heterosexual citizens, the native population, and so forth. It does not then express the universalism and inter-community bridging goals that civil society typically emphasises. It limits itself to bonding strategies aimed at its like-minded supporters.

Although their presence comes mainly from member states, in recent years CUCS has also started to approach the EU level more directly. This became visible in 2013 through a blog entitled Agenda Europe (2021), with a focus on European politics and expressing a strong traditionalist perspective on issues of sexuality and reproductive rights. The organisation of the same name hosting the blog meets biannually and is financed by a small group of wealthy donors, and in recent years it has assembled in London, Munich, Dublin, and Warsaw. Agenda Europe has become the primary organisation of conservative civil society, promoting over a dozen recent initiatives to hinder women's and LGBT human rights initiatives through European institutions (Datta, 2018).

Among its tools, Agenda Europe's blog is particularly important. It shows “a Brussels insider's perspective, as the comments follow political developments in the European Union (EU) institutions closely and demonstrate an understanding of EU decisionmaking" (Datta, 2018: 6). At the EU level, this organisation promotes advocacy on a set of key issues: a strategy against euthanasia; a strategy for religious freedom; a strategy for marriage and the family; a strategy opposing antidiscrimination legislation; and a strategy against surrogacy. Agenda Europe's strategies also include the publication of a 134-page manifesto entitled Restoring the Natural Order: an Agenda for Europe (Datta, 2018: 10).

As a coalition, Agenda Europe relates to other organisations which have varying degrees of permanence and independence from specific member states. One of these organisations is, for instance, the Observatory on Intolerance and Discrimination against Christians in Europe (2021). The organisation is registered as a member of the Fundamental Rights Platform of the EU-Fundamental Rights Agency. As such, it participates in a network for cooperation and information exchange between the Fundamental Rights Agency of the EU and CSOs active in the field of fundamental rights. It is then included in consultations just like other organisations such as churches, religious and philosophical organisations, NGOs dealing with human rights, and other associations. 
In these contexts, it thus attempts to acquire legitimacy and initiate a process of institutionalisation. Among other activities, it produces annual reports and states that it exerts advocacy on behalf of "Christians". However, it counsels its members to exercise caution in their interactions with supranational institutions because they are seen as inspired by conflicting values and, therefore, as opponents. Moreover, its manifesto encourages sympathetic organisations to apply for EU funds. As Datta argues, Agenda Europe is an international CSO which includes representatives of political parties from a range of political institutions, including centre-right and populist radical-right parties in the EU Parliament (Datta, 2018: 20).

Other socially conservative organisations, even if they do not aspire to the role of umbrella networks, play a similar role of attempting to gain political relevance, resources, and impact in EU political institutions, and in this context to advance a socially conservative agenda. Notable in this regard is the Polish Ordo Iuris (2021) which has a proactive stance in targeting international organisations, as shown by this excerpt from its website:

We are involved in the activities of the Council of Europe, the OSCE and the $\mathrm{UN}$, however, a special role in this respect is played by the permanent presence of Ordo Iuris at the institutions of the European Union and the operation of the Institute's office in Brussels.

Nonetheless, it should be reiterated that the role of conservative civil society groups in international organisations is still generally controversial, and their representation claims are often not accepted. Their conflictual stand is acknowledged and is part of a long-term legitimating strategy. For instance, the participation of radically conservative associations in the UN meeting in Nairobi is described on their website in terms that clarify their "out of the system" character:

At the international UN summit in Nairobi, an attempt will be made to recognise abortion as a human right and to impose forced and vulgar sexual education on the countries. The event is attended by representatives of pro-abortion organisations, including Planned Parenthood. Despite the difficulties created by the summit's, experts from the Ordo Iuris Institute are also participating in the event as representatives of one of the few organisations that defend life and family. (Ordo Iuris, 2019)

It should be noted, however, that precisely because of conservative associations' strategic self-placement as boundary organisations, the divide between a socially conservative agenda and an agenda that tolerates and encourages discrimination on various grounds - and notably sexuality - is often difficult to clearly identify. There is a continuity between CUCS and other socially non-progressive organisations. For these reasons, only CSOs clearly rejecting EU antidiscrimination policies have been selected for analysis.

\section{Frame analysis of CUCS in relation to progressive civil society}

The frame analysis of CUCS documents answers the question of what these organisations prioritise and how different their recurrent topics to those of progressive CSOs are. Each of the codes identified relates to themes that are also often present in the texts of progressive CSOs, but are in a different position in the ranking and are interpreted 
in opposite ways. Only a partial analysis of these findings is possible here, but before providing examples of key frames, it is useful to note the overall difference between the two political discourses.

The different political discourses of CSOs and CUCS emerge clearly when comparing their respective rankings of frames. In the case of CUCS, taken all together, the set of frequently emerging frames point to a strong emphasis on the concept of natural law, which is emphatically seen as taking priority over socially approved legal codes. This hierarchy of frames is shown by the relative frequency of high-level codes, that is, issues on which a position in favour or against can be held. Thus, the discourse of CUCS is strongly concerned with the following topics, which are ranked in terms of frequency: natural order/law/family, religion (for and against), and sexual and/or reproductive discrimination. Conversely, topics less frequently mentioned are those that are central in progressive CSOs: migration, sexual exploitation, human rights, gender issues/gender gap, environment, women, labour market, terrorism, genocide, actions (taken or to be taken) against (different types of) discrimination, fascism, Islamophobia, rule of law, far-right politics, violence, Covid-19, democracy in the EU, social justice, EU funding/budget, EU values, racism, nationalism, populism. These preferences are then, for instance, claimed to justify rejections of European antidiscrimination law and policies. Comparatively, their discourse is also notable for its thematic absences. For instance, they never conceptualise issues of hate speech, which are crucial for progressive CSOs.

The political discourses of CUCS reflect their subordinate role at the EU level. Several of their prominent arguments are responses to the value priorities of other CSOs, such as when they pay particular attention to issues of sexual discrimination and to the role of women denying that their traditionalist positions are discriminatory against women. Migration is prominent in their position papers and is seen as a threat, particularly "uncontrolled migration". A cluster of frames concerns issues pertaining to the extreme right. They, for instance, note incidents when their activities or symbols have been attacked by anti-fascists, who are seen as vandalising Catholic bookstores and spraying anti-fascist graffiti. However, the discourse of EU CUCS appears different from the uncompromising hard-right discourse one might find in radical-right parties in member states. For instance, documents stress the necessity to protect migrant children from abuse, which is a topic one also finds in progressive CSOs.

\section{Boundary-making in conservative uncivil society}

Statements such as those in favour of migrant children illustrate the process of boundarymaking. The CUCS groups that were identified at the EU level are socially conservative organisations, but not as extreme as many uncivil society groups in member states. They distance themselves from violent organisations that might appear as lacking compassion for the social groups they oppose. Conversely, the progressive CSOs' ordered list of topics points to a strong concern with issues of racism and racial discrimination and to a lesser extent to a cluster of concerns with other areas of discrimination: racism, human rights, migration, civil society, gender issues/gender gap, hate speech and crime, discrimination, far-right politics, rule of law, actions (taken or to be taken) against (different types of) discrimination, Islamophobia, Roma, violence. These concerns are often framed in relation to human rights and to the positive role that civil society can 
play in addressing these social vulnerabilities. As previously mentioned, this points to a self-legitimating and all-encompassing role for CSOs.

In particular, there are two clusters where the difference is particularly stark: human rights and homosexuality, which are conceptualised differently but are very important in the two families of CSOs. While for CUCS, homosexuality frequently emerges as an offence against the natural order or as a denial that sexual discrimination is perpetrated by those who are opposed to homosexuality, for progressive CSOs, it is framed as a status of social vulnerability to be protected. A few excerpts will clarify the position of CUCS.

\section{Sexual discrimination}

In the below excerpt, the use of derogatory language reinforces not only principled opposition to normalise homosexuality but expresses a rejection of the EU Treaty articles and directives that regulate the matter.

The "normality" of sodomy is itself another important, if not the most important, communicative objectives of the gay lobby. The purpose is to make sodomites look "like everyone else" [...] Given that marriage has a procreative purpose (i.e. to create a stable basis for a man and a woman to raise children), it is an absurdity to adopt laws that allow "marriages" between persons of the same sex. (Agenda Europe, 2021)

Homosexuality is negatively moralised and framed in emotional terms in the below excerpt. CUCS realise that they are fighting against established EU principles, and their goal is to oppose what they fear are taken-for-granted principles and policy assumptions in the EU community. Thus, they do not only address progressive CSOs, but specifically EU institutions, such as its parliament:

According to a report adopted by the European Parliament in 2012, "homophobia is the irrational fear of, and aversion to, male and female homosexuality and lesbian, gay, bisexual and transgender (LGBT) people based on prejudice, and is similar to racism, xenophobia, anti-Semitism and sexism" [...]. At the same time, however, it is not only possible, but also a necessity, to distinguish good actions from evil ones. [...] Disapproval of sodomy is not irrational fear or aversion, but it is a sound moral judgment based on compelling rational reasons [...]. It is therefore perfectly reasonable to disapprove of sodomy, or to warn one's children against engaging in it. These views are nothing we ought to feel ashamed for. (Agenda Europe, 2021)

Thus, the boundary-making activities of CUCS utilise a strategic mix of using emotions, moralising issues, opposing established norms, and disparaging representatives of the LGBT community.

\section{Human rights}

Another key difference is on the frame human rights, which is relevant because it is one of the most frequently identified frames, coming second in progressive civil society and fifth in CUCS ranking and referring to the idea that human rights are important and should be protected. In this case, CUCS does not oppose the idea of human rights but alters its use. Thus, the ambit of application of human rights is different in the two families of CSOs. The following examples describe human rights for CUCS: 
It is therefore wrong to say that the legal recognition of same sex "marriages" has no negative impact on the existing concept of marriage between a man and a woman. [...] The introduction of same sex "marriage" deprives, in a certain sense, all non-homosexuals of the right to contract an authentic marriage, and thus arguably constitutes a violation of human rights. (Agenda Europe, 2021)

In recent years, various UN Treaty monitoring bodies have come forward with temerarious re-interpretations of the international treaties that have been entrusted to them, pretending that an implicit "right to abortion" lay somewhere hidden in those treaties. Those interpretations are false and pretentious, and rather than providing credibility to any claim that abortion is a human right they undermine the credibility of the institutions and persons making them. (Agenda Europe, 2021)

Access to abortion: it has many times explicitly been clarified that the term "reproductive rights" does not include a right to abortion [...]. The European Court of Human Rights has clearly stated that the European Human Rights Convention contains no implicit "right to abortion". Hence there is no "consensus". Abortion is not a therapy, and pregnancy is not a disease. (Agenda Europe, 2021)

Conversely, progressive CSOs conceptualise human rights differently, as shown by the following excerpts:

At a time where European societies are confronted with rising extremism, radicalism and divisions, it is more important than ever to uphold and strengthen EU values of equality between women and men and human rights. (European Women's Lobby, 2021)

It is now time for the European institutions, civil society organisations and all citizens believing in democracy and human rights to speak up, recognise the nature and the cause of hate speech directed towards Roma. (European Roma Grassroots Organizations, 2021)

At a time when hate speech and divisive rhetoric cause a worrying backlash and backsliding for all human rights across Europe, ILGA-Europe considers it crucial to unite with a broad and diverse alliance of organisations to take a clear stand against hate speech and divisive rhetoric. (International Lesbian and Gay Association, 2021)

Thus, in the case of human rights and of homosexuality, two different boundary-making strategies are at work. In one case, opponents define the other as socially dangerous and emotionally unacceptable. However, in the case of human rights, the competence in the framing operation of the opponent - or even its honesty in interpreting reality - are called into question.

\section{Conclusions}

This article has documented the contrasting discourses of conservative and progressive civil society. I argued that their framing contrast encapsulated the current state of civil society at the EU level and is best interpreted as a struggle between a movement of populism and its opponents. Several authors have characterised contemporary 
right-wing populism as a movement and anti-populism as a counter-movement, and they have described the confrontational nature of their exchanges (Aslanidis, 2017). This confrontation goes well beyond electoral politics and spills out in a set of social domains, including organised civil society. The exchanges between the two camps also take place within EU institutions and in EU-level civil society. Anti-populist actors at the EU level worry about the way in which populist political discourse has impacted European societies and their civil societies, and they focus on how to combat what they perceive as a loss of relevance and a "shrinking space" for civil society (Alston, 2017). The EU-level embedding of contrasting families of CSOs attenuated this conflict, but it remains a vital feature of the state of European civil society. Nonetheless, it is still a conflict in its infancy, as progressive CSOs dominate the civil society field and align with EU values to an extent that they are unlikely to see their institutional support diminish. However, CUCS enjoys a growing ascendancy due to the organisational and conceptual weakness of antipopulism. This is due to the often-tangled strategies of antipopulists. On key issues such as the nativist views of populists, they often fail to express a coherent strategy (Titley, 2014). In addition, once the cultural views of populists have taken roots - particularly anti-elitism - it becomes difficult for all political elites to fight them effectively. Antipopulist formations fight an uphill struggle and often fail to mobilise effectively (Van Dyck, 2019). This difficulty is then echoed at the EU level.

Conversely, CUCS groups express antipluralist values and attempt to achieve a modicum of institutionalisation in an environment that they still perceive as largely hostile. However, they are gaining strength and visibility in countries where populist parties are in incumbent positions. Populists' recent successes in the 2019 European elections are likely to make them increasingly valuable to support the political role of populist parties. This is in part because a conservative, and particularly a traditionalist Christian, stance can unify populist parties that differ substantially in terms of other issues, such as foreign and economic policies. Populist parties and conservative CSOs might differ on many issues, but they are likely to be unified by their common allegiance to an exclusionary set of values that negates the worth of social inclusion and instead emphasises law-and-order policies, traditional family values, and protection of the native population against what they perceive as cultural hybridisation.

Nonetheless, CUCS needs to share a political environment with institutionalised progressive associations that express different values and have undergone a different trajectory. A different type of institutionalisation concerns progressive civil society, for which institutionalisation takes place within the dominant ideological and organisational system of EU governance (Ruzza, 2015). In their institutionalisation, they also face dilemmas related to the conflict between retaining their critical stances, which is a defining feature of civil society, but acquiring and retaining sufficient access and legitimacy (Alexander, 1998). However, to achieve this goal, they have taken a different approach. Their political stance and action repertoire ignores or mildly criticises some of the defining values of the EU - such as its emphasis on neoliberalism and increasingly on New Public Management - but strongly espouses its inclusionary values. The process of institutionalisation excludes associations less willing to accept this compromise. As a result of these dynamics, an interaction between "moderate" uncivil society associations and "moderate" civil society associations shapes EU civil society. Nonetheless, the progressive field is significantly larger and more relevant than the domain of conserva- 
tive civil society, and the ideological distance between the two is too considerable for significant collaboration to be envisaged. They are principled opponents.

However, these considerations - as well as the prominent display of images of populist leaders holding rosaries and crosses in their political campaigns - should not obscure the fact that uncivil society comes in multiple shades. It is useful to reiterate that the most extreme kinds of CUCS groups, such as vigilante groups harassing migrants in the streets, are not the same as ultraconservative religious organisations, in terms of the suffering they can dispense. Nevertheless, ignoring or denying the validity of the body of antidiscrimination laws is also a violation of the general ethos of civil society in the EU, and these violations must be documented and analysed, as they have consequences for the lives and wellbeing of a range of minorities. It is also important to study this cleavage within the body of populist associations, because they are also becoming prominent in member states and internationally.

A representative of this type is the international conservative event, World Congress of Families, which is an international set of events organised by a civil society conservative coalition based in the US promoting Christian-right values and opposing same-sex marriage, pornography, and abortion. It is unconstitutional on several grounds. For instance, it opposes legal protections on the basis of sexual orientation, which at the EU level is specifically protected by Article 13 (now 19) of the Amsterdam Treaty (Council of the European Union, 1997) in addition to being protected by Article 2 of Treaty on European Union (European Union, 2012). However, this organisation is held in high esteem and was, for instance, hosted by the Hungarian government at a large reception in 2017. In 2019, it organised its annual event in Verona, Italy, during a large meeting of pro-family anti-abortion groups, which was attended by Matteo Salvini, the leader of the Italian Lega party, a prominent populist formation which attracts the support of a large share of Italian voters (Kalm \& Meeuwisse, 2020). This meeting was part of a set of similar international meetings, such as a meeting held in conjunction with the International Organisation for the Family. This organisation defines its mission as equipping leaders worldwide with the means to promote the natural family. These values are then fostered by CUCS in member states - and not only at the EU level - for instance, in March 2017, by the president of Generation Family (an organisation founded in France under the name La Manif pour tous).

Nonetheless, in most member states, the boundaries between civil and uncivil society are drawn mainly by focusing on other kinds of organisations. While the conservative religious dimension might be used as a populist-unifying strategy, it is often not the main divide. Instead, the divide is often based on xenophobia as the populist-defining signature policy, with the notable exception of populist governments in the Visegrád countries where xenophobia and illiberal conservatism are closely connected (Krzyżanowska \& Krzyżanowski, 2018; Majtényi et al., 2019). The fact that at the EU level, CSOs divide along traditionalist religious lines shows the environmentally defined nature of boundary-making, as argued by Johan Gøtzsche-Astrup (2019). Xenophobic organisations are screened out by the process of institutionalisation in the EU environment, but not Christian traditionalist ones, even if they oppose key constitutionalised values. This also depends on the flexible, changeable boundaries between the civil and the uncivil in traditionalist civil society and the ever-present potential for obfuscation by CSOs acting strategically in their political environment (Gøtzsche-Astrup, 2019). 


\section{Funding}

Research for this article was supported by the Italian Research Council Grant, "The Transformations of Democracy: Actors, Strategies and Outcomes in Opposing Populism in Political, Juridical and Social Arenas" (2018-2020).

\section{References}

Alexander, J. C. (Ed.). (1998). Real civil societies: Dilemmas of institutionalization. London: Sage.

Alston, P. (2017). The populist challenge to human rights. Journal of Human Rights Practice, 9(1), 1-15. https://doi.org/10.1093/jhuman/hux007

Aslanidis, P. (2017). Populism and social movements. In C. R. Kaltwasser, P. A. Taggart, P. O. Espejo, \& P. Ostiguy (Eds.), The Oxford handbook of populism (pp. 305-325). Oxford: Oxford University Press. https://doi.org/10.1093/oxfordhb/9780198803560.001.0001

Collins, H., Evans, R., Durant, D., \& Weinel, M. (2020). Experts and the will of the people: Society, populism and science. London: Palgrave Macmillan. http://doi.org/10.1007/978-3-030-26983-8

Council of the European Union. (1997). Treaty of Amsterdam Amending the Treaty on European Union, The Treaties Establishing the European Communities and Related Acts. http://data.europa.eu/eli/treaty/ ams/sign

Datta, N. (2018). Restoring the natural order: The religious extremists'vision to mobilise European societies against human rights on sexuality and reproduction. European Parliamentary Forum on Population \& Development. https://www.epfweb.org/sites/default/files/2020-05/rtno_epf_book_lores.pdf

de la Torre, C., \& Mazzoleni, O. (2019). Do we need a minimum definition of populism? An appraisal of Mudde's conceptualisation. Populism, 1(1), 1-12. https://doi.org/10.1163/25888072-02011021

European Union. (2012). Consolidated version of the Treaty on European Union. Official journal, C326/115. http://data.europa.eu/eli/treaty/teu_2012/oj

Grote, J. (2019). Civil society and the European Union: From enthusiasm to disenchantment. https://docresearch.org/2019/11/civil-society-european-union-enthusiasm/

Gøtzsche-Astrup, J. (2019). Civil society and its outside: Analysing the boundary between civil and uncivil society in the Danish anti-radicalisation discourse. Journal of Civil Society, 15(2), 162-177. https://doi. org/10.1080/17448689.2019.1595382

Kalm, S., \& Meeuwisse, A. (2020). For love and for life: Emotional dynamics at the World Congress of Families. Global Discourse, 10, 303-320. https://doi.org/10.1332/204378920X15784019972237

Krzyżanowska, N., \& Krzyżanowski, M. (2018). 'Crisis' and migration in Poland: Discursive shifts, anti-pluralism and the politicisation of exclusion. Sociology, 52(3), 612-618. https://doi. org/10.1177\%2F0038038518757952

Krzyzanowski, M., \& Ledin, P. (2017). Uncivility on the web populism in/and the borderline discourses of exclusion. Journal of Language and Politics, 16(4), 566-581. https://doi.org/10.1075/jlp.17028.krz

Majtényi, B., Kopper, Á., \& Susánszky, P. (2019). Constitutional othering, ambiguity and subjective risks of mobilisation in Hungary: Examples from the migration crisis. Democratization, 26(2), 173-189. https:// doi.org/10.1080/13510347.2018.1493051

Matthes, J. (2009). What's a frame? A contents analysis of media framing studies in the world's leading communication journals 1990-2005. Journalism \& Mass Communication Quarterly, 86(2), 349-367. https:// doi.org/10.1177\%2F107769900908600206

Ruzza, C. (2010). Identifying uncivil society in Europe: Towards a 'new politics of the enemy'? In U. Liebert, \& H.-J. Trenz (Eds.), The new politics of European civil society (pp. 143-162). London: Routledge. https://doi.org/10.4324/9780203836682

Ruzza, C. (2015). Changes in the field of EU civil society organizations: Institutionalisation, differentiation and challengers. In H. Johansson, \& S. Kalm (Eds.), EU civil society: Patterns of cooperation, competition and conflict (pp. 23-42). London: Palgrave. https://doi.org/10.1057/9781137500724

Saurugger, S. (2016). Democratic 'misfit'? Conceptions of civil society participation in France and the European Union. Political Studies, 55(2), 384-404. https://doi.org/10.1111\%2Fj.1467-9248.2007.00662.x

Saward, M. (2010). The representative claim. Oxford: Osford University Press. https://doi.org/10.1093/acpr of:oso/9780199579389.001.0001

Titley, G. (2014). After the end of multiculturalism: Public service media and integrationist imaginaries for the governance of difference. Global Media and Communication, 10(3), 247-260. https://doi. org/10.1177\%2F 1742766514552351

Van Dyck, B. (2019). Why not anti-populist parties? Theory with evidence from the Andes and Thailand. Comparative Politics, 51(3), 361-388. 
The institutionalisation of populist political discourse and conservative uncivil society in the European Union

Wodak, R. (2017). Doing politics' in the European Parliament. In G. Clemens (Ed.), The quest for Europeanization: Interdisciplinary perspectives on a multiple process (pp. 187-206). Stuttgart: Franz Steiner Verlag.

\section{Empirical material cited}

Agenda Europe. (2021). Agenda Europe. [blog]. Retrieved January 21, 2021, from https://agendaeurope. wordpress.com

European Roma Grassroots Organizations. (2021). ERGO. Retrieved January 21, 2021, from https://www. mediavoice.eu/en/soho_portfolio/ergo/

European Women's Lobby. (2021). European women's lobby: Together for a feminist Europe. Retrieved January 21,2021 , from https://womenlobby.org/?lang=en

FEMYSO. (2018, November 30). CDDH: Protection and promotion of the civil society space in Europe. Retrieved January 21, 2021, from https://femyso.org/cddh-protection-and-promotion-of-the-civilsociety-space-in-europe/

International Lesbian and Gay Association. (2021). ILGA-Europe. Retrieved January 21, 2021, https://www. ilga-europe.org

Observatory on Intolerance and Discrimination against Christians in Europe. (2021). About us. Retrieved January 21, 2021, from https://www.intoleranceagainstchristians.eu/about-us/\#aboutUs

Ordo Iuris. (2019, November 13). A stand for the defence of life and family at the United Nations forum: Ordo Iuris is participating in the Nairobi Summit. http://en.ordoiuris.pl/life-protection/stand-defencelife-and-family-united-nations-forum-ordo-iuris-participating-nairobi

Ordo Iuris. (2021). International Activity. Retrieved January 21, 2021, from http://en.ordoiuris.pl/internationalactivity

(C) 2021 Nordicom and respective authors. This is an Open Access work licensed under the terms of the Creative Commons Attribution-NonCommercial-NoDerivatives 4.0 International Public licence (CC BY-NC-ND 4.0). To view a copy of the licence, visit https://creativecommons.org/ licenses/by-nc-nd/4.0/ 